\title{
STUDY OF V. O. SUKHOMLYNSKYI'S ACTIVITY AS A STRATEGY OF V. O. SUKHOMLYNSKYI STATE SCIENTIFIC AND PEDAGOGICAL LIBRARY OF UKRAINE
}

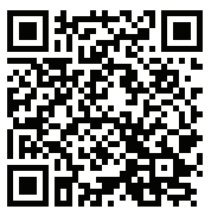

To cite this article:

\author{
Larysa Berezivska, Dr. Sc., Prof. \\ Director, V.O. Sukhomlynskyi State Scientific \\ and Pedagogical Library of Ukraine \\ Kyiv, Ukraine \\ lberezivska@ukr.net \\ https://orcid.org/0000-0002-5068-5234
}

\begin{abstract}
Honouring the 100-th anniversary of the birth of an outstanding Ukrainian teacher-humanist $V$. O. Sukhomlynskyi, the 39th session of the General Conference of UNESCO stated the problem of study of V. O. Sukhomlynskyi's activity as a strategy of V. O. Sukhomlynskyi State Scientific and Pedagogical Library of Ukraine. The following aim of the study is realised in the article: having analysed annual reports and materials available on the Library web portal and in the reading room of $V$. O. Sukhomlynskyi's collection, and research papers, the author revealed organisational and content principles of the SSPL activity regarding the development of study of V. O. Sukhomlynskyi's heritage. It is argued that the SSPL being a structural part of the National Academy of Educational Sciences of Ukraine carries out research, information, and socio-cultural work dedicated to the study of V. O. Sukhomlynskyi's activity as a topical direction of pedagogy. The following used forms are characterised: carrying out cultural and educational activities (excursions and thematic lectures; dramatisation of fairy tales and stories; exhibitions of children's creative works on V. O. Sukhomlynskyi's fictions; reading fairy tales and stories by children and librarians), and theoretical and practical activities (round tables, seminars, conferences, library section within the framework of pedagogical readings), and creation of information resources, databases, and bio bibliographic indexes. The information on the results in the area of study of V. O. Sukhomlynskyi's activity is available on the Library web portal. The leading role of the SSPL in the development of study of V. O. Sukhomlynskyi's activity within the information space is proved. The author considers it necessary to understand on an interdisciplinary basis the information resources created by other libraries and educational institutions in order to study and popularise the ideas of the outstanding Ukrainian teacher under conditions of the development of the New Ukrainian School.

Key words: information space of Ukraine; study of V. O. Sukhomlynskyi's activity; V. O. Sukhomlynskyi's pedagogical oeuvre; V. O. Sukhomlynskyi State Scientific and Pedagogical Library of Ukraine.
\end{abstract}




\section{INTRODUCTION. PROBLEM STATEMENT}

Nowadays, when education reform takes place in Ukraine, teachers and scholars study the ideas of an outstanding teacher, scientist, Director of Pavlysh secondary school, publicist, and children's writer Vasyl Oleksandrovych Sukhomlynskyi in order to understand and introduce them into the practice of educational institutions. Considering this and honouring the 100-th anniversary of the birth of the outstanding Ukrainian teacher-humanist V. O. Sukhomlynskyi, the 39-th session of the General Conference of UNESCO stated the problem of study of V. O. Sukhomlynskyi's activity as a strategy of V. O. Sukhomlynskyi State Scientific and Pedagogical Library of Ukraine (hereinafter referred to as the SSPL). With the assistance of the Department of General Pedagogy and Philosophy of Education of the National Academy of Educational Sciences (NAES) of Ukraine, the SSPL realises one of its strategies, viz. it develops the study of V. O. Sukhomlynskyi's activity as a special phenomenon that unites scientists and educators around the study and popularisation of the teacher's ideas. It is no coincidence, as the SSPL provides information support to education in Ukraine.

\section{LITERATURE REVIEW}

The historiographical search showed that the development of Ukrainian and foreign study of V. O. Sukhomlynskyi's activity was systematically highlighted in research papers by Ukrainian scientists (L. D. Berezivska, H. V. Bielan, N. A. Kalinichenko, V. H. Kuz, O. Ya. Savchenko, O. V. Saraieva, L. P. Parkhieta, O. V. Sukhomlynska and others) (Berezivska, 2015; Bielan, 2014; Kalinichenko, 2005; Kuz, 2011; Savchenko, 1998, 2003; Saraieva, 2008; Parkhieta, 2009; Sukhomlynska, 2005) and foreign scientists (A. Cockerill (Australia), E. Hartmann (Germany), Zhu Xiaoman (China), H. Frangos (Greece) and others) (Cockerill, 1994; Hartman, 2010; Siaoman, 2010; Frangos, 1998). Some other Ukrainian researchers wrote about the following aspects of activity performed by the SSPL in the area of study of V.O. Sukhomlynskyi's heritage: opening of the reading room of V. O. Sukhomlynskyi's collection (L. M. Zalitok, 2003; L. I. Tkachenko, 2003 and others), naming the library after V. O. Sukhomlynskyi (V. Zotova, 2004 and others), opening of the monument to V. O. Sukhomlynskyi in the library (O. Pechenezka, 2008 and others), the state Ukrainika Naukova (Scientific Ukrainika) abstract database as one of the segments for popularising the study of V. O. Sukhomlynskyi's activity (L. Zalitok, 2014), the importance of bibliographic indexes about V. O Sukhomlynskyi's oeuvre and study of his papers by other researchers and teachers (T. Dobko, 2009 and others), holding the library section within the framework of pedagogical readings (I. Khemchian, 2011). However, the problem of multiple-aspect activities performed by the SSPL regarding the development of study of V. O. Sukhomlynskyi's activity as a component of pedagogy requires a complex interpretation.

\section{METHODOLOGY}

The main aim of the article is to reveal organisational and content principles of activity performed by the SSPL regarding the development of study of V. O. Sukhomlynskyi's heritage within the information space of Ukraine on the basis of the analysis of annual reports and materials available on the Library web portal and in the reading room of 
V. O. Sukhomlynskyi's collection, and research papers. In order to realise the aim of the research, the following set of methods and approaches was used: general research (historical and pedagogical analysis, synthesis, generalisation, chronological); historiographical; source study; biographical; axiological; informational; monitoring of the website content.

\section{MAIN RESULTS}

It should be noted that the study of V. O. Sukhomlynskyi's activity is an important direction in the history of pedagogy regarding the study of V. O. Sukhomlynskyi's oeuvre. The SSPL joined this direction in 2003, when a reading room of V.O. Sukhomlynskyi's collection was opened on 24 April 2003 with the assistance of the teacher's family (his wife Hanna Ivanivna, children Olga Vasylivna and Serhii Vasyliovych) and the All-Ukrainian Association of Vasyl Sukhomlynskyi. The first Director of the SSPL P. I. Rohova, PhD (History) played an important role in the development of study of V. O. Sukhomlynskyi's activity in the Library under the direct guidance of the academician O. V. Sukhomlynska. According to O. Ya. Savchenko, the opening of the reading room of V. O. Sukhomlynskyi's collection will help readers of Ukraine to reach the unique materials presented by Vasyl Sukhomlynskyi's family (Savchenko, 2003: p. 20).

With the assistance of the leaders of the NAES of Ukraine, in particular academicians V. H. Kremen, O. Ya. Savchenko, O. V. Sukhomlynska, and All-Ukrainian Association of Vasyl Sukhomlynskyi the Library was named in honour of Vasyl Oleksandrovych Sukhomlynskyi (according to the Ordinance of the Cabinet of Ministers of Ukraine No. 664 adopted on 5 November 2003). Later, in commemoration of the 90-th anniversary of V. O. Sukhomlynskyi's birth (on 29 September 2008), the first monument in Kyiv to the teacher was opened in the SSPL.

Since the study of V. O. Sukhomlynskyi's oeuvre is a topical one, there is a great number of research papers about the teacher and his ideas, editions and new editions of his works in the educational space. It caused the SSPL to carry out scientific and information work on systematisation of appropriate materials and creation of thematic biographical information resources and bio bibliographic indexes taking into account new computer technologies and information potential.

Now the scientists of the Library continue to develop thestudy of V.O.Sukhomlynskyi's activity and popularise the teacher's ideas in the following forms: the reading room of V. O. Sukhomlynskyi's collection, the sector on study of V. O. Sukhomlynskyi's activity of the History of Education Department (2016), the members of which carry out research work (they write research papers and prepare biobibliographic indexes); excursions, lectures, round tables, seminars, and book exhibitions. The following constantly updated information resources are available on the library web portal: Vasyl Oleksandrovych Sukhomlynskyi (1918-1970) page, Reading room of V. O. Sukhomlynskyi's collection page, Sukhomlynskyi Vasyl Oleksandrovych resource being a component of an information bibliographic Outstanding teachers of Ukraine and the world resource, Study of $V$. O. Sukhomlynskyi's activity database, etc.

In 2017, the reading room of V. O. Sukhomlynskyi's collection being a structural part of the sector on study of V. O. Sukhomlynskyi's activity of the History of Education Department was renewed. Its document collection holds more than 5,000 items. Among them are: V. O. Sukhomlynskyi's works in the Ukrainian and 50 foreign languages; publications devoted to the teacher and materials concerning the use of the 
teacher's pedagogical oeuvre; publications (V.O. Sukhomlynskyi's papers and papers about him) from periodicals, their copies (1976-1977), and documentary films about the teacher (http://dnpb.gov.ua).

The following systematic cultural, educational, theoretical, and practical events are held for pupils, students, postgraduate students, doctoral candidates, educators, and researchers in the reading room: excursions to the reading room of V. O. Sukhomlynskyi's collection of the SSPL; thematic lectures within the framework of the scientific and pedagogical lecture titled ' $V$. O. Sukhomlynskyi's pedagogical oeuvre in modern information space'; round tables, theoretical and practical seminars, etc. Among them are: round table dedicated to the 25-th anniversary of the founding of the Ukrainian Association of Vasyl Sukhomlynskyi (2015), round table titled 'Vasyl Sukhomlynskyi "Difficult fates": let's read together' (commemorating the 50t-h anniversary of the book's publication) (2016), theoretical and practical seminar titled 'Vasyl Sukhomlynskyi and modern preschool education' (2018), round table titled 'Sukhomlynskyi is written to' (2018), etc.

The All-Ukrainian Association of Vasyl Sukhomlynskyi founded in November 1990 functions based on the Library under the direction of an academician O. Ya. Savchenko; it plays an important role in the development of study of V. O. Sukhomlynskyi's activity. This voluntary public unit, which unites Ukrainian and foreign teachers, actively studies, popularises, and introduces V. O. Sukhomlynskyi's oeuvre into the educational space. Due to the systematic, innovative, and diverse activity carried out by the Association, study of V. O. Sukhomlynskyi's activity is popular not only in Ukraine, but in many countries around the world. The Association holds pedagogical readings, scientific conferences, methodical lessons, and seminars (Savchenko, 1998).

In 2015, the SSPL held a round table dedicated to the 25-th anniversary of founding of the All-Ukrainian Association of Vasyl Sukhomlynskyi. The main aim of this round table was to sum up and define prospects of the activity carried out by the Library regarding the development of study of V. O. Sukhomlynskyi's activity.

A significant contribution to the development of study of V. O. Sukhomlynskyi's activity is holding the library section within the framework of pedagogical readings titled 'Vasyl Sukhomlynskyi is in dialogue with modern times'. Since 2007, 11 library sections have been held for school librarians from different regions of Ukraine within the framework of pedagogical readings. Within the framework of anniversary pedagogical readings titled 'Vasyl Sukhomlynskyi is in dialogue with modern times: Vasyl Sukhomlynskyi's oeuvre in the national and international dimensions' the library section will unite library workers from Kropyvnytskyi town and Kirovohrad oblast in the format of the round table titled 'Value dimensions of school library as a part of the education space' (2018). The information about library sections and research papers written by the Library scientists and school librarians is available in the scientific and methodological Shkilna Biblioteka Plius (School Library Plus) journal.

On the Library initiative and in order to popularise V. O. Sukhomlynskyi's ideas in the librarian space, the All-Ukrainian month of school libraries will be held in 2018 under the following slogan: 'School library: centre of creative development of a child' (commemorating the 100-th anniversary of V. O. Sukhomlynskyi's birth). The activities of leading education libraries dedicated to the celebration of the 100-th anniversary of V. O. Sukhomlynskyi's birth will be reflected in the guide titled 'Guide on scientific, information, and publishing activities, and main events aimed at improving professional skills of library workers in the sphere of education' (2018). 
One of the traditional forms of popularisation of V. O. Sukhomlynskyi's ideas is book exhibitions; in general, more than 60 book exhibitions were organised by the SSPL. Among them are: ' $V$. O. Sukhomlynskyi's ideas in the context of modern educational problems' (2009), 'V. O. Sukhomlynskyi in the context of modern education and information society' (2011), 'Vasyl Sukhomlynskyi: a guide of pedagogy of humanity' (2012), 'Vasyl Sukhomlynskyi's ideas on the formation of a healthy life-style in modern pedagogical theory and practice' (2012), 'V. O. Sukhomlynskyi's pedagogy in the context of development of a creative personality' (2013), 'V. O. Sukhomlynskyi's humanistic pedagogy in the context of educating tolerant personality' (2014), 'Formation of tolerance through the prism of Vasyl Oleksandrovych's pedagogical ideas' (2015), 'V. O. Sukhomlynskyi's humane pedagogy as a source of spirituality' (2015), 'V. O. Sukhomlynskyi's ideas as a conceptual basis of the national and patriotic education' (2016), 'I and my family: fairy world' (2016), 'Commemorating the 50th anniversary of V. O. Sukhomlynskyi's book titled "Difficult fates": let's read together' (2017), 'V. O. Sukhomlynskyi's ideas on the national and patriotic education of children of preschool and primary school age' (2018), 'Sukhomlynskyi is written to' (2018), 'V. O. Sukhomlynskyi's works published in foreign languages' (2018), 'Vasyl Sukhomlynskyi and modern preschool education' (2018). In order to arrange an exhibition it is necessary to create catalogues, that is a list of sources presented at the exhibition. The information about exhibitions and appropriate sources is available on the Library web portal.

The academician O. V. Sukhomlynska consulted the researchers of the Library, and they prepared three editions of bibliographic index about V. O. Sukhomlynskyi's life and activity (2001, 2008, 2013) (Sukhomlynska, 2001; Sukhomlynska, Rohova, Zalitok, 2008; Sukhomlynska, Rohova, Zalitok, 2014). In order to popularise the teacher's heritage in Ukraine and abroad the researchers of the Library published the most complete bibliographic index titled 'Vasyl Oleksandrovych Sukhomlynskyi: commemorating the 100th anniversary of his birth'. This index contains publications devoted to V. O. Sukhomlynskyi's life and oeuvre for the 1945-2017. These indexes are the source and information base for the integral historical and educational study of V. O. Sukhomlynskyi's pedagogical ideas and fictions, as well as information about studies of his papers on education and introduction of his ideas into educational practice. We consider V. O. Sukhomlynskyi's pedagogical oeuvre to be a topical one under conditions of the development of New Ukrainian School, because it is an inexhaustible source on various issues in the sphere of educational theory and practice since it is characterised by its multi-vector and childcentred orientation. Therefore, there is no doubt that the bibliography will be constantly enriched with research papers in Ukraine, as well as abroad.

The information and bibliographic Outstanding teachers of Ukraine and the world resource (2008-2018) plays an important role in dissemination of study of V. O. Sukhomlynskyi's activity. This resource is an integral part of the national humanitarian space. Vasyl Oleksandrovych Sukhomlynskyi resource contains the following structural parts: the teacher's biography, bibliography of his papers and materials about him; some full-text works; photo gallery; societies, associations, and establishments, bearing his name; information about awards, prizes, monuments, pedagogical readings, and Internet resources connected with the name of this outstanding figure (Sukhomlynskyi Vasyl Oleksandrovych, 2018).

Undoubtedly, the information bibliographic resource is very important for the development of pedagogical science in general, and study of V. O. Sukhomlynskyi's 
activity in particular. It performs the following functions: it enriches historical and pedagogical knowledge about V. O. Sukhomlynskyi and his contribution to the development of science and practice (enrichment of the content of textbooks on history of education and pedagogical thought); it provides information support to historical and pedagogical science (material for writing dissertations and research works); it helps in training future teachers (material for writing bachelor and master theses); it is used while holding mass scientific and practical events (conferences, round tables, etc.) dedicated to V. O. Sukhomlynskyi's creative activity; it provides information in order to hold scientific, educational, and public activities at various levels. At the same time, it helps to disclose the Library collection, pedagogical sources in particular; to deepen information requests of a wide range of remote users of Ukraine and the world (researchers, teachers, students, postgraduates, doctoral candidates) on various problems regarding study of V. O. Sukhomlynskyi's activity. It should be noted that the mentioned resource is constantly updated in electronic form in line with new achievements in the sphere of historical and pedagogical studies, that is, in the future, it will comprehensively cover the teacher's life and activity in the national and foreign education space.

\section{CONCLUSIONS}

The SSPL being a structural part of the NAES of Ukraine carries out research, information, and socio-cultural activities concerning the study of V. O. Sukhomlynskyi's activity as a topical direction of pedagogy. Nowadays the following forms are used: carrying out cultural and educational activities (excursions and thematic lectures for educators, future teachers, and librarians; dramatisation of fairy tales and stories; exhibitions of children's creative works on V. O. Sukhomlynskyi's fictions; reading fairy tales and stories by children and librarians), and theoretical and practical activities (round tables, seminars, conferences, library section within the framework of pedagogical readings), and the creation of information resources, databases, and bio bibliographic indexes. The information on the results and experience in the area of study of V. O. Sukhomlynskyi's activity is available on the Library web portal, and this information is a component of the information space of Ukraine.

The SSPL plays a leading role in the development of study of V. O. Sukhomlynskyi's activity within the information space of Ukraine. However, we consider it necessary to understand on an interdisciplinary basis the information resources created by other libraries and educational institutions in order to study and popularise the ideas of the outstanding Ukrainian teacher under conditions of the development of the New Ukrainian School. This will be discussed in our further publications.

\section{REFERENCES}

Berezivska, L. D. (2015). Derzhavna naukovo-pedahohichna biblioteka Ukrainy imeni V.O Sukhomlynskoho jak intehrator i poshyriuvach pedahohichnoho biohrafichnoho znannia [V.O. Sukhomlynskyi State Scientific and Pedagogical Library of Ukraine as an integrator and disseminator of pedagogical biographical knowledge]. Ukrainskyi pedahohichnyi zhurnal, 3, 209-219.

Bielan, H. V. (2014). Suchasni naukovi pidkhody do vyvchennia spadshchyny V.O. Sukhomlyn- 
skoho: typolohichnyi kontsept [Modern scientific approaches to study of V.O. Sukhomlynskyi's oeuvre: typological concept]. Naukovyi visnyk mykolaivskoho natsionalnoho universytetu imeni V.O. Sukhomlynskoho. Pedahohichni nauky: zbirnyk naukovykh prats, 1.47, 26-31.

Hartmann, E. V. (2010). V. O. Sukhomlynskyj: krytyk radianskoi ta kapitalistychnoi systemy. Novyi pohliad na spadshchynu klasyka pedahohiky [V.O. Sukhomlynskyi as a critic of the Soviet and capitalist system. A new look on the oeuvre of the classic of pedagogy]. Shliakh osity, 1, 32-37.

Kalinichenko, N. A. (2005) Suchasnyky Vasylia Sukhomlynskoho [Vasyl Sukhomlynskyi's contemporaries]. Pedahohichni nauky: zbirnyk naukovyh prats, 40, 207-211.

Cockerill A. L. (1994) V.O. Sukhomlynskyi. Humanizm v radianskii shkoli [Humanism in the Soviet school]. Brisben, University of Queensland.

Kuz, V. H. (2011). Sukhomlynistyka - nova paradyhma elitnoho vykhovannia [Study of V.O. Sukhomlynskyi's activity as a new paradigm in elite education]. Pedahohichnyi dyskurs: zbirnyk naukovykh prats, 10, 268-272.

Parkheta, L. P. (2009). Istoriohrafia vyvchennia spadshchyny V.O. Sukhomlynskoho [Historiography of study of V.O. Sukhomlynskyi's oeuvre]. Vytoky pedahohichnoi majsternosti. Seria: pedahohichni nauky: zbirnyk naukovykh prats, 6, 31-37.

Savchenko, O. Ya. (2003). Rozvytok sukhomlynistyky za desiat rokiv (1993-2003 rr.) [Development of study of V.O. Sukhomlynskyi's activity during 10 years (1993-2003)]. Naukovi zapysky. Seria: pedahohichni nauky, 52, part 1, 18-22.

Savchenko, O. Ya. (1998). Tovarystvo poslidovnykiv idej Vasylia Sukhomlynskoho [Society of followers of Vasyl Sukhomlynskyi's ideas]. Pochatkova shkola, 9, 1-4.

Saraieva, A. (2008). Sukhomlynistyka jak aktualnyi napriam istoryko-pedahohichnykh doslidzhen. [Study of V.O. Sukhomlynskyi's activity as a topical trend in historical and pedagogical research]. Naukovi zapysky. Seria: pedahohichni nauky, Kirovohrad. 78, part 1, 159-163.

Sukhomlynska, O. V. (2005). Sukhomlynskyi Vasyl Oleksandrovych [Sukhomlynskyi Vasyl Oleksandrovych]. Ukrainska pedahohika $v$ personaliakh: navchalnyi posibnyk dlia studentiv vyshchykh navchalnykh zakladiv: kn.2, 380-386.

V.O. Sukhomlynskyi. Biobibliohrafia: 1987-2000 rr.: Bibliohrafichnyi pokazhchyk (2001). [V.O. Sukhomlynskyi. Biobibliography, 1987-2000: bibliographic index]. Kyiv: Kyiv National Economic University.

V.O. Sukhomlynskyi. Biobibliohrafia: 2001-2008 rr.: Bibliohrafichnyi Pokazhchyk (2008). [V.O. Sukhomlynskyi. Biobibliography, 2001-2008: bibliographic index]. Kyiv: Kyiv National Economic University.

V.O. Sukhomlynskyi. Biobibliohrafia:2008-2013 rr.: Bibliohrafichnyi Pokazhchyk (2014). [V.O. Sukhomlynskyi. Biobibliography, 2008-2013: bibliographic index]. Vinnytsia: TOV 'Nilan-Ltd'.

Vasyl Oleksandrovych Sukhomlynskyi [Vasyl Oleksandrovych Sukhomlynskyi]. V.O. Sukhomlynskyi. State scientific and pedagogical library of Ukraine. Retrieved from http://dnpb.gov.ua/ uа/інформаційно-бібліографічні-ресурси/видатні-педагоги/сухомлинський-в-о

Franhos, H. (1993). Vid Sokrata do V. Sukhomlynskoho cherez Zh. Piazhe ta L. Vyhotskoho: Kopernykiv perevorot v osviti [From Socrates to V. Sukhomlynskyi through Jean Piaget and L. Vyhotskyi: Copernic's revolution in education]. Pochatkova shkola, 10, 18-20.

Chzhu Syaoman (2010). Vplyv pedahohichnykh idei V.O. Sukhomlynskoho na rozvytok osvity $\mathrm{v}$ suchasnomu Kytai i mizhnarodnomu spivavtorstvi [Influence of V.O. Sukhomlynskyi's pedagogical ideas on the development of education in modern China and international coauthorship]. Ridna shkola, 3, 20-22. 